
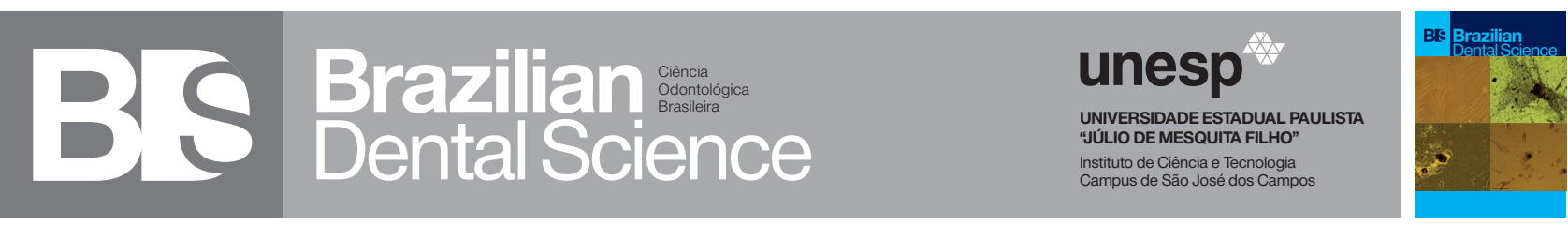

\title{
The long-term effect of sparkling flavored water on human tooth enamel determined by gravimetric analysis: a preliminary evaluation
}

O efeito a longo prazo da água aromatizada com gás no esmalte dental humano determinado por análise gravimétrica: uma avaliação preliminar

Shivaughn MARCHAN ${ }^{1}$, Kelee BASCOMBE ${ }^{2}$, Trevin HECTOR $^{2}$, William SMITH ${ }^{2}$, Terry RAMNANANSINGH ${ }^{3}$

1 - Unit of Restorative Dentistry - School of Dentistry - the University of the West Indies - St Augustine - Trinidad and Tobago.

2 - School of Dentistry - the University of the West Indies - St Augustine - Trinidad and Tobago.

3 - School of Pharmacy - the University of the West Indies - St Augustine - Trinidad and Tobago.

\begin{abstract}
Objective: The aim of this study was to assess the in vitro effect of flavored waters on human tooth enamel using a gravimetric method. Lingual surfaces of lower molars were used to obtain enamel specimens. Material and Methods: Enamel $(n=3)$ was washed and dried, immersed in 6 flavors of locally available flavored sparkling water and assessed using gravimetric analysis, periodically for up to 9 days. Additionally, $\mathrm{pH}$ measurements of the flavored waters were recorded. Results: All the tested flavored waters showed $\mathrm{pH}$ values below that of critical $\mathrm{pH}$. Paired t-tests demonstrated significant reductions in the mean group mass for all enamel specimens from as early as day 1 after immersion in flavored water, compared to baseline measurements. Further reductions in mean mass continued up to day 9 of immersion. Conclusion: Flavored waters are potentially erosive to human enamel specimens with the erosive effect being cumulative over time.
\end{abstract}

\section{KEYWORDS}

pH; Enamel; Dental erosion.

\section{RESUMO}

Objetivo: O objetivo deste estudo foi avaliar o efeito in vitro de águas aromatizadas no esmalte dental humano utilizando um método gravimétrico. Material e Métodos: As superfícies linguais dos molares inferiores foram utilizadas para obter amostras de esmalte. O esmalte $(n=3)$ foi lavado, seco, e posteriormente imerso em 6 diferentes águas aromatizadas com gás disponíveis na região, e avaliado periodicamente por até 9 dias através de análise gravimétrica. Além disso, as medições de $\mathrm{pH}$ das águas aromatizadas foram registradas. Resultados: Todas as águas aromatizadas testadas apresentaram valores de $\mathrm{pH}$ abaixo do $\mathrm{pH}$ crítico. Os testes $\mathrm{t}$ pareados demonstraram reduções significativas na massa média do grupo para todas as amostras de esmalte desde o primeiro dia após a imersão em água com sabor, em comparação com as medições de referência. Reduções adicionais na massa média continuaram até o nono dia de imersão. Conclusão: As águas aromatizadas são potencialmente erosivas para as amostras de esmalte humano, sendo o efeito erosivo cumulativo ao longo do tempo.

\section{PALAVRAS-CHAVE}

pH; Esmalte; Erosão dentária. 


\section{INTRODUCTION}

$\mathrm{T}$ he effect of beverages such as soft drinks, sports and energy drinks on tooth tissue loss by extrinsic erosion is well documented [1-3]. The erosive effect of these beverages on enamel have been quantified in many in-vitro experiments [1-3]. Some of the invitro methods utilized to quantify the erosive potential of beverages on hard tissue are: chemical methods, light microscopy methods, mechanical methods and tests of permeability [4].

Flavored waters are relatively new in the beverage industry. Global market research has predicted an international increase in the sale of flavored bottled water in the next 3 to 5 years based on: perceived health benefits of such beverages compared to sodas, juices, sports and energy drinks; urbanization and greater disposable income of consumers $[5,6]$. These increases have been predicted to take place in China, India and Latin America $[5,6]$. Little is known on the long and short-term erosive effects of these beverages on dental hard tissue.

Many in vitro methods require the use of enamel that must be prepared by being ground and polished i.e. the enamel samples are described as non-native [4]. Zimmer et al described a method for quantifying erosive tooth loss using gravimetric analysis that precluded the complex and time-consuming specimen preparation associated with the aforementioned methods [7]. Gravimetric methods involve the precise determination of absolute mass of dental hard tissue before and after immersion in an acidic solution for a specific length of time [8].

When evaluating the effect of food and beverages on dental hard tissue, the rate and mechanics of enamel dissolution are particularly important since highly mineralized enamel acts as the initial barrier to overall tooth surface loss. Once less mineralized dentine is exposed the rate of dentine loss is greater than that of enamel giving rise to the characteristically cupped out lesions noted on occlusal surfaces [9].

Nyugen et al determined the erosive potential of flavored water enhancers on dental hard tissue using gravimetric analysis [10]. Water enhancers are packaged liquid or powdered flavors meant to be added to plain water by the consumer. The methodology, however, determined loss of mass from entire teeth as a result of immersion in water flavored with water enhancers [10]. This study gave limited information on the effect of such beverages on enamel alone as the effect on both dentine and enamel were determined simultaneously.

The aim of this study is to determine the erosive effect of sparkling flavored waters on human enamel using gravimetric analysis. The null hypotheses stated there would be no difference in the mean mass of enamel samples immersed in flavored beverages compared to control over the observed time period.

\section{MATERIAL AND METHODS}

An exemption from the Campus Research and Ethics Committee of The University of the West Indies, St. Augustine was gained prior to the start of this study (CE824/01/19). The sparkling flavored waters used in the study are listed in Table 1, along with their respective ingredient lists.

$\mathrm{pH}$ of the sparkling flavored waters used in this study was determined with a $\mathrm{pH}$ meter using a double junction glass $\mathrm{pH}$ electrode (Oakton pH150, Oakton Instruments) at room temperature. Prior to $\mathrm{pH}$ measurements being taken the $\mathrm{pH}$ meter was calibrated against a buffering solution containing deionized water, sodium phosphate dibasic, potassium phosphate monobasic, sodium chromate and potassium dichromate (Orion Research Incorporated). Two $\mathrm{pH}$ measurements were taken at a room temperature of $25 \mathrm{oC}$, of $50 \mathrm{ml}$ of each beverage poured directly from the bottle. A mean $\mathrm{pH}$ reading was calculated based on the two readings. 
Human lower molars where selected for the study from a tooth bank of extracted teeth at the University of the West Indies School of Dentistry. A diamond disc at slow speed, using water coolant was used to obtain enamel samples alone of uneven sizes from the lingual surfaces of each tooth, after the roots were first de-coronated. The methodology of gravimetric analysis warranted no further preparation of the samples. Each lingual surface produced 2-3 enamel samples, with a total of 27 enamel samples being produced. Samples were all stored together in distilled water after preparation, with 3 enamel samples $(n=3)$ being randomly allocated to each group of flavored water. Plain carbonated water (Pellegrino, Pellegrino Terre) served as the positive control. Distilled water served as the negative control.

Enamel samples were washed with distilled water, placed in a dry heat oven (Protectop, Ruby Labs Inc) at $100 \mathrm{oC}$ for 1 hour to remove excess water and stored in a desiccator temporarily until each sample could be weighed on an analytic balance to an accuracy of 0.0001 $\mathrm{g}$ (Veritas, H\&C Weighing Systems).

Thirty milliliters of each flavored water were dispensed into a petri-dish. Three dried enamel samples were placed in each solution ensuring total immersion of each sample and the petri-dish covered to prevent evaporation of water and a change in the concentration of ingredients of the flavored waters. Enamel samples were kept immersed in flavored water solutions for the entire time until each evaluation period. Samples were weighed at 1,6,8 and 9 days after washing, drying and storing as described above. After each evaluation period, the enamel samples were placed in $30 \mathrm{ml}$ of replenished flavored water directly from a new bottle. Data was entered in SPSS Version 24 (IBM Corporation). Group means and standard deviations were calculated and paired t- tests used to determine whether there were significant differences in group means for each time interval compared to baseline measurements at the 0.05 p-level.
Table 1 - Brand, Flavor and ingredient list of sparkling flavored waters used in this study

\begin{tabular}{|c|c|c|}
\hline BRAND & WATER & INGREDIENTS \\
\hline $\begin{array}{c}\text { Blue } \\
\text { Waters }\end{array}$ & $\begin{array}{l}\text { Sparkling } \\
\text { Cran Plus }\end{array}$ & $\begin{array}{l}\text { Carbonated water, Sugar, Citric Acid, Natural } \\
\text { Flavour, Malic Acid, Sodium Hexametaphosphate, } \\
\text { Sodium Benzoate \& Potassium Sorbate, Vegeta- } \\
\text { ble Juice Concentrate, Caramel Colour, Sucralose, } \\
\text { Panax Ginseng Root Extract, Calcium Disodium } \\
\text { EDTA, Amaranth Red, Vitamin A, VitaminE }\end{array}$ \\
\hline \multirow{4}{*}{ Viva } & $\begin{array}{l}\text { Strawberry } \\
\text { Melon }\end{array}$ & $\begin{array}{l}\text { Carbonated Water, Apple Juice Concentrate, Citric } \\
\text { Acid, Natural Strawberry and Melon Flavours, Po- } \\
\text { tassium Benzoate and Potassium Sorbate, Sucra- } \\
\text { lose, Green Tea Extract, Acesulfame Potassium, } \\
\text { Magnesium Sulphate, Inositol, Calcium Disodium } \\
\text { EDTA, Niacinamide, FD\&C Red \#40, Calcium } \\
\text { D-Pantothenate, Pyridoxine Hydrochloride }\end{array}$ \\
\hline & $\begin{array}{l}\text { Orange } \\
\text { Mango }\end{array}$ & $\begin{array}{c}\text { Carbonated Water, Apple Juice Concentrate, Citric } \\
\text { Acid, Potassium Benzoate and Potassium Sor- } \\
\text { bate, Green Tea Extract, Sucralose, Acesulfame } \\
\text { Potassium, Natural Orange and Mango Flavours, } \\
\text { Gum Acacia, Ester Gum, Calcium Disodium EDTA, } \\
\text { Magnesium Sulphate, Inositol, FD\&C Yellow \#6, } \\
\text { Niacinamide, Calcium D-Pantothenate,FD\&C } \\
\text { Yellow \#5, Pyridoxine Hydrochloride }\end{array}$ \\
\hline & Peach & $\begin{array}{l}\text { Carbonated Water, Apple Juice Concentrate, Citric } \\
\text { Acid, Natural Peach Flavours, Potassium Ben- } \\
\text { zoate and Potassium Sorbate, Green Tea Extract, } \\
\text { Acesulfame Potassium, Sucralose, Magnesium } \\
\text { Sulphate, Inositol, Calcium Disodium EDTA, Nia- } \\
\text { cinamide, Calcium D-Pantothenate, FD\&C Yellow } \\
\text { \#6, Pyridoxine Hydrochloride, FD\&C Red \#40, }\end{array}$ \\
\hline & $\begin{array}{c}\text { Black } \\
\text { Raspberry }\end{array}$ & $\begin{array}{l}\text { Carbonated Water, Apple Juice Concentrate, Malic } \\
\text { Acid, Natural Black Raspberry Flavours, Potas- } \\
\text { sium Benzoate and Potassium Sorbate, Sucralose, } \\
\text { Green Tea Extract, Acesulfame Potassium, Mag- } \\
\text { nesium Sulphate, Inositol, FD\&C Red \#40, Calcium } \\
\text { Disodium EDTA, Niacinamide, Calcium D-Panto- } \\
\text { thenate, Pyridoxine Hydrochloride, FD\&C Blue\#1 }\end{array}$ \\
\hline $\begin{array}{l}\text { Sparkling } \\
\text { Ice }\end{array}$ & $\begin{array}{c}\text { Pink } \\
\text { Grapefruit }\end{array}$ & $\begin{array}{c}\text { Carbonated Water, Citric Acid, Grapefruit Juice } \\
\text { Concentrate, Natural Flavours, Potassium Ben- } \\
\text { zoate, Gum Arabic, Sucralose, Vegetable Juice, } \\
\text { Ester Gum, Green Tea Extract, Calcium Disodium } \\
\text { EDTA, Biotin, Niacinamide, Beta Carotene, Vitamin } \\
\text { A, Calcium Pantothenate, Vitamin B12, Vitamin D3, } \\
\text { Pyridoxine Hydrochloride }\end{array}$ \\
\hline Kirkland & $\begin{array}{l}\text { Orange } \\
\text { Mango }\end{array}$ & $\begin{array}{l}\text { Carbonated Water, Contains < } 2 \% \text {, of Green Tea, } \\
\text { Vitamin D3, Niacin, Calcium Pantothenate, Pyri- } \\
\text { doxine Hydrochloride, Biotin, Vitamin B12, Natural } \\
\text { Flavors, Sucralose, Citric Acid, Arabic Gum, Ester } \\
\text { Gum, Yellow 6, Yellow 5, Potassium Benzoate }\end{array}$ \\
\hline $\begin{array}{c}\text { San } \\
\text { Pellegrino }\end{array}$ & $\begin{array}{c}\text { S. } \\
\text { Pellegrino }\end{array}$ & Carbonated Mineral Water \\
\hline
\end{tabular}




\section{RESULTS}

All the tested waters, with the exception of distilled water were deemed acidic. The results of the $\mathrm{pH}$ measurements for the tested flavored waters are shown in Table 2. The mean (S.D.) mass of the enamel samples at tested times are shown in Table 3. The percentage reduction of group mean mass for each group, from baseline is shown in Table 4. Statistical analysis clearly demonstrated differences in the group means between baseline and all successive evaluation periods $(\mathrm{p}<0.05)$ for enamel samples immersed in the flavored waters. Additionally, there were significant differences in group means between all evaluation periods and each subsequent evaluation period.

For the plain sparkling water there were reductions in mean mass that were significantly different from baseline measurements for the Day 1 and Day 6 only. For Day 8 and 9 there were no significant changes from baseline or between Day 6 and subsequent evaluation periods $(\mathrm{p}>0.05)$.

Table 2 - The mean $\mathrm{pH}$ of tested flavored sparkling waters

\begin{tabular}{|cc|}
\hline Brand/Flavor of Water & Mean $\mathbf{~ H ~}$ \\
\hline Blue Waters Sparkling Cran Plus & 1.82 \\
\hline Viva Strawberry Melon & 1.97 \\
\hline Viva Peach & 1.92 \\
\hline Viva Orange Mango & 1.83 \\
\hline Viva Black Raspberry & 1.96 \\
\hline Sparkling Ice Pink Grapefruit & 1.70 \\
\hline Kirkland Orange Mango & 2.05 \\
\hline Pellegrino Sparkling Water & 4.35 \\
\hline Distilled Water (Control) & 7.00 \\
\hline
\end{tabular}

Table 3 - Group means and standard deviations of enamel samples at each time interval (Different superscript symbols show significant differences in mean mass from baseline measurements)

\begin{tabular}{|c|c|c|c|c|c|}
\hline \multirow[b]{2}{*}{$\begin{array}{c}\text { Brand/Flavor of } \\
\text { Water }\end{array}$} & \multicolumn{5}{|c|}{ \% Reduction in mass from Baseline } \\
\hline & $\begin{array}{l}\text { Base- } \\
\text { line }\end{array}$ & Day 1 & Day 6 & Day 8 & Day 9 \\
\hline \multirow{2}{*}{$\begin{array}{c}\text { Blue Waters } \\
\text { Sparkling Cran Plus }\end{array}$} & $0.2078+$ & $0.2007^{\star}$ & $0.1910^{\star}$ & $0.1818^{\star}$ & $0.1799^{*}$ \\
\hline & $(0.0698)$ & $(0.0708)$ & $(0.0714)$ & $(0.0727)$ & $(0.0720)$ \\
\hline \multirow{2}{*}{$\begin{array}{l}\text { Viva Strawberry } \\
\text { Melon }\end{array}$} & $0.2358+$ & $0.2226^{\star}$ & $0.2013^{\star}$ & $0.1838^{*}$ & $0.1781^{*}$ \\
\hline & $(0.0793)$ & $(0.0780)$ & $(0.0768)$ & $(0.0792)$ & $(0.0780)$ \\
\hline \multirow{2}{*}{ Viva Peach } & $0.3487+$ & $0.3336^{\star}$ & $0.3091^{*}$ & $0.2897^{*}$ & $0.2814^{\star}$ \\
\hline & $(0.0832)$ & $(0.0810)$ & $(0.0789)$ & $(0.0753)$ & $(0.0747)$ \\
\hline \multirow{2}{*}{ Viva Orange Mango } & $0.3345+$ & $0.3139^{\star}$ & $0.2814^{*}$ & $0.2458^{\star}$ & $0.1998^{\star}$ \\
\hline & $(0.0327)$ & $(0.0333)$ & $(0.0356)$ & $(0.0367)$ & $(0.0389)$ \\
\hline \multirow{2}{*}{$\begin{array}{l}\text { Viva Black } \\
\text { Raspberry }\end{array}$} & $0.2716+$ & $0.2595^{\star}$ & $0.2200^{*}$ & $0.1992^{*}$ & $0.1907^{\star}$ \\
\hline & $(0.0399)$ & $(0.0253)$ & $(0.0391)$ & $(0.0369)$ & $(0.0358)$ \\
\hline \multirow{2}{*}{$\begin{array}{l}\text { Sparkling Ice Pink } \\
\text { Grapefruit }\end{array}$} & $0.3388+$ & $0.3174^{*}$ & $0.2817^{\star}$ & $0.2561^{*}$ & $0.2458^{*}$ \\
\hline & $(0.1627)$ & $(0.1202)$ & (0.1163) & (0.1108) & $(0.1077)$ \\
\hline \multirow{2}{*}{$\begin{array}{l}\text { Kirkland Orange } \\
\text { Mango }\end{array}$} & $0.1998+$ & $0.1822^{*}$ & $0.1491^{\star}$ & $0.1286^{*}$ & $0.1187^{\star}$ \\
\hline & $(0.0600)$ & $(0.0565)$ & $(0.0534)$ & $(0.0485)$ & $(0.0448)$ \\
\hline \multirow{2}{*}{$\begin{array}{l}\text { Pellegrino Sparkling } \\
\text { Water }\end{array}$} & $0.3221+$ & $0.3177^{\star}$ & $0.3190^{*}$ & $0.3100^{*}$ & $0.3114^{*}$ \\
\hline & $(0.0444)$ & $(0.0432)$ & $(0.0438)$ & $(0.0372)$ & $(0.0375)$ \\
\hline \multirow[t]{2}{*}{ Distilled Water } & $0.3470+$ & $0.3476+$ & $0.3490+$ & $0.3437+$ & $0.3454+$ \\
\hline & (0.1352) & (0.1344) & $(0.1347)$ & (0.1318) & (0.1329) \\
\hline
\end{tabular}

Table 4 - Percentage change in mass compared to baseline

\begin{tabular}{|c|c|c|c|c|}
\hline $\begin{array}{c}\text { Brand/Flavor of } \\
\text { Water }\end{array}$ & Day1 & Day 6 & Day 8 & Day 9 \\
\hline $\begin{array}{c}\text { Blue Waters } \\
\text { Sparkling Cran Plus }\end{array}$ & 3.4 & 8.1 & 12.5 & 13.4 \\
\hline $\begin{array}{l}\text { Viva Strawberry } \\
\text { Melon }\end{array}$ & 5.6 & 14.6 & 22.1 & 24.5 \\
\hline Viva Peach & 4.3 & 11.4 & 17.0 & 19.3 \\
\hline Viva Orange Mango & 6.2 & 15.9 & 26.6 & 40.3 \\
\hline Viva Black Raspberry & 4.5 & 19.0 & 26.7 & 29.8 \\
\hline $\begin{array}{l}\text { Sparkling Ice Pink } \\
\text { Grapefruit }\end{array}$ & 6.3 & 16.9 & 24.4 & 27.4 \\
\hline $\begin{array}{l}\text { Kirkland Orange } \\
\text { Mango }\end{array}$ & 8.8 & 25.4 & 35.6 & 41.0 \\
\hline $\begin{array}{l}\text { Pellegrino Sparkling } \\
\text { Water }\end{array}$ & 1.4 & 1.0 & 3.8 & 3.3 \\
\hline Distilled water & 0.0 & 0.6 & 0.9 & 0.5 \\
\hline
\end{tabular}




\section{DISCUSSION}

In-vitro tests of the erosive potential of acidic drinks are known to occur at faster rates that are possibly not comparable to in vivo rates of wear. This is due to factors such as the salivary buffering capacity, the length of time in contact with teeth and the protective effect of salivary pellicle. [11-14] In vitro tests, however, allow a baseline understanding of the effect of various beverages on dental hard tissue. All of the tested samples demonstrated $\mathrm{pH}$ values well below neutral $\mathrm{pH}$ of 7 and critical $\mathrm{pH}$ of 5.5 , at which demineralization of enamel is expected to occur.

Low $\mathrm{pH}$ values observed amongst the tested flavored waters are indicative of dissociated hydrogen ions that could interact with hydroxyapatite and fluorapatite in a process termed proton promoted dissolution $[15,16]$. Examination of the ingredient list of the tested flavored waters revealed citric acid added directly to the formulations and indirectly in the form of fruit juices such as natural grapefruit, apple or orange juice. Additionally, malic acid added both directly or indirectly in the form of apple juice concentrate can be found in some of the formulations. Both these organic acids have the potential to dissociate into hydrogen ions. The sparkling flavored waters demonstrated both low $\mathrm{pH}$ values and erosive potential; determined by the loss of observed mass for the enamel samples. All the tested flavored waters caused appreciable tissue loss as evidenced by the reduction in total group mean mass ranging from the $13.4-41 \%$. There are however other factors that affect the dissolution mechanics of enamel such as the concentration of calcium and phosphate ions in solution of the assessed beverage [17]. Beverages that are under- saturated with calcium and phosphate ions, with low $\mathrm{pH}$ are more likely to be erosive in nature, causing net loss from dental hard tissue until the beverage is at equilibrium with the tested enamel samples. Given that the beverages were refreshed after each evaluation period, the rate of erosion proceeded at a faster rate since equilibration between enamel samples and the various beverages never occurred.

It is noteworthy to point out that Blue Waters Sparkling Cran Plus which contains sodium hexametaphosphate produced the lowest rates of erosion measured using this gravimetric analysis. Sodium hexametaphosphate is a conjugated phosphate that is often used as an additive in beverages as an emulsifier and has also been evaluated as a remineralization agent for exposed dentine [18]. The addition of this conjugated phosphate would increase phosphate concentrations in solution, counterbalancing the loss of hydroxyapatite even at the lowest measured $\mathrm{pH}$ of 1.82 .

The flavored waters were also used at a room temperature of 25oC. Chilled acidic beverages are expected to have lower dissociation constants [13]. Barbour et al conclusively demonstrated a linear increase in erosive enamel loss as a result of temperature increase [19].

Assuming an individual would drink one bottle of water per day, taking a total of 5 mins to consume, the immersion times in this study would translate into approximately 7 years of normal tooth exposure. The successive loss of tooth tissue by dissolution was evident in this study at each of the evaluated periods and concurs with the findings of Jager et al who demonstrated a linear relationship between erosion and time [20].

It was surprising that plain carbonated water also demonstrated a mild erosive effect as early as Day 1, albeit at a much slower rate. This could be attributed to the effect of dissolved carbon dioxide which produces weak carbonic acid. It has been shown that plain carbonated water can affect the microhardness of enamel samples based on the level of carbonation [21]. A reduction in the microhardness of enamel samples has been demonstrated with erosive beverages [4]. 
This preliminary study into the erosive potential of flavored sparkling waters on the effect of enamel showed significant reduction in the mean mass when immersed in sparkling flavored waters, however there are limitations to the study. The protective effect of pellicle was not considered. The exposure of enamel to flavored water, used in this study, cannot be considered normal. In reality, enamel will be the exposed to any beverage for intermittent periods of times with the diluting and washing effect of saliva. Translation of normal beverage use into an in vitro methodology could possibly involve subjecting enamel samples to beverages for shorter periods of time using agitation. Additionally, true correlation of the $\mathrm{pH}$ of the sparkling flavored waters with erosive tooth loss could not be investigated. This would involve the measurement of $\mathrm{pH}$ at each of the immersion time points to capture a data structure that would facilitate real correlation.

Future research by the authors will involve a detailed analysis of the physiochemical properties of locally produced and marketed flavored beverages and to determine the effect of pellicle on the erosive potential of such beverages on both enamel and dentine. The effect of these beverages on the buffering capacity of saliva also needs to be evaluated.

\section{CONCLUSIONS}

Within the limitations of this study, flavored waters are potentially erosive to dental enamel both in the short, medium and long term, with evidence that the erosive effect is cumulative over time.

\section{Acknowledgements}

The authors would like to acknowledge lab technicians; Ms. Shirla Latchman and Mr. Derek Ackbar of the School of Dentistry, St. Augustine for their support during use of the lab facilities. We would also like to thank Dr. Marsha Ivey for her statistical advice.

\section{REFERENCES}

1. von Fraunhofer JA, Rogers MM. The dissolution of enamel in soft drinks. Gen Dent. 2004 Jul-Aug;52(4):308-12.

2. Damo DM, Arossi GA, da Silva HA, dos Santos LH. Erosive potential of sports beverages on human enamel in vitro. Rev Bras Med Esporte. 2018;24(5):38690. doi: 10.1590/1517-869220182405165861

3. Pinto SCS, Bandeca MC, Silve CN, Cavassim R, Borges AH, Sampaio JEC. Erosive potential of energy drinks on the dentine surface. BMC Res Notes. 2013 Feb 19;6:67. doi: 10:1186/1756-0500-6-67.

4. Attin T.Methods of assessment of dental erosion. Monogr Oral Sci. 2006;20:152-172 doi:10.1159/000093361.

5. Market Research Futures. Flavored water market global research report by type (carbonated, non-Carbonated), flavor (lemon, orange, mixed berry, apple and others), packaging Material (glass, plastic), distribution channel (store and non-Store) and region - Forecast till 2023. ID: MRFR/F-B \& N/4025-HCRR, May,2019.

6. Prescient and Strategic Intelligence. Global flavored and functional water market size, share, development, growth and demand forecast to 2024. Market Research Report Code CP10071

7. Zimmer S, Kircher G, Bizhang M, Benedix M. Influence of Various Acidic Beverages on tooth erosion evaluation by a new method. PLoS One. 2015;10(6):e0129462. doi:10.1371/journal.pone.0129462.

8. von Fraunhofer JA, Rogers MM. Effect of sports drinks and other beverages on dental enamel. Gen Dent. 2005 Jan-Feb;53(1):28-31.

9. Ganss C, Lussi A. Diagnosis of erosive wear. Monogr Oral Sci. 2014;25:22-31. doi: 10.1159/000359935. Epub 2014 Jun26.

10. Nguyen C, Ghuman T, Ahmed SN, Donovan TE. The erosive potential of additive artificial flavoring in bottled water. Gen Dent. 2018 Sep-0ct;66(5):46-51.

11. TenutaLMA, Fernandez CS, Brandao ACS, Cury JA. Titratable acidity of beverages influences salivary pH recovery. Braz Oral Res. 2015;29. pii: S180683242015000100234. doi: 10.1590/1807-3107BOR-2015.vol29.0032. Epub 2015 Feb 11.

12. Hellwig E, Lussi A, GoetzF.Influence of human saliva on the development of artificial erosions. Caries Res. 2013;47(6):553-8. do: 10.1159/000351634. Epub 2013 Jul 3.

13. Milosevic A. Sports drinks harzards to teeth. Br J Sports Med. 1997 Mar;31(1):28-30.

14. Aljawad A, Morgan AZ, Fairchild R, Rees JS. Investigation of the erosive potential of sour novelty sweets. Br Dent J. 2017 Apr 21;222(8):613-620. doi: 10.1038/sj.bdj.2017.363.

15. Shellis RP,Featherstone JDB, Lussi A. Understanding the chemistry of dental erosion. Monogr Oral Sci. 2014;25:163-79. doi:10.1159/000359943. Epub 2014 Jun26.

16. Stumm W.Chemistry of the Solid-Water Interface. New York. Wiley 1992.428p.

17. Jensdottir T, Bardow A, Holbrook P.Properties and modification of soft drinks in relation to their erosive potential in vitro. J Dent. 2005 Aug;33(7):569-75. Epub 2005 Feb 16.

18. Buzalaf MAR, Magalhaes AC, Wiegand A. Alternatives to fluoride in the prevention and treatment of dental erosion. Monogr Oral Sci. 2014;25:244-52. doi: 10.1159/000360557. Epub2014 Jun 26.

19. Barbour ME, Finke M, Eisenburger M, Parker DM, Addy M. Relationship between enamel softening and erosion caused by soft drinks at a range of temperatures. J Dent 2006 Mar;34(3):207-13. Epub2005 Aug 19. 
20. Jager DHJ, Vieira AM, Ruben MC, Huysmans DNJM. Estimated erosive potential depends on exposure time. J Dent. 2012 Dec;40(12):1103-8. doi: 10.1016/.j.jent.2012.09.004. Epub2012Sep 19.
21. Ryu H, Kim Y,Heo S, Kim S. Effect of carbonated water manufactured by a soda carbonator on etched or sealed enamel. Korean J Orthod. 2018 Jan;48(1):4856. doi: 10.4041/kjod.2018.481.48. Epub 2017 Nov 19.

\section{Dr. Shivaughn Marchan \\ (Corresponding address)}

Unit of Restorative Dentistry, School of Dentistry, Faculty of Medical Sciences,

The University of the West Indies, Mount Hope Medical Complex, Champs Fleurs,

Trinidad, West Indies.

Date submitted: 2019 Sep 20

E-mail: shivaughn.marchan@sta.uwi.edu

Accept submission: 2019 Nov 25 